\title{
GEOGRAFIAS EM TELA, PERSPECTIVAS EM REDE
}

\author{
Gabriela Fiorin Rigotti ${ }^{1}$; \\ Gabriela Guarnieri de Campos Tebet ${ }^{2}$
}

Este número da Revista ETD é lançado em meio ao segundo ano de contingenciamento social devido à pandemia de COVID-19. Cerca de dezoito meses depois da detecção do primeiro acometimento pela infecção, ainda nos encontramos isolados, exilados dos afetos, retirados da vida em comum. Insulados por trás das telas, ramificamos rizomas ${ }^{3}$ por entre o que é caseiro e ordinário, tentando nos manter emersos da aguaça de dores e inseguranças que ultrapassam - e muito, sobretudo no Brasil - as manifestações sintomáticas advindas de um vírus.

Por debaixo do dossel de poderes que, se deveria nos resguardar, ou nos queima ou nos tira a luz, uma pipocante costura de vida trançada e contínua segue. Um micélio emaranhado e astuto de práticas e estudos brotados em lugares distintos, que se conecta às capilares referenciais de autores variados e cresce e se encontra com outros rizomáticos prontos a (se)(nos) expandir e transformar.

Assim é o dossiê As Telas da Escola: cinema e professores de Geografia - perguntas e reflexões em torno de uma pesquisa, proposto por Wenceslao Machado de Oliveira Jr, Flaviana Gasparotti Nunes e Gisele Girardi e que trazemos neste número. Reunindo 8 artigos, o coletivo de textos aqui apresentado é como uma micorriza a aumentar nossa capacidade de absorver dulçores e alimentar branduras, ainda que protegida e incitada pela serrapilheira das dores decompostas daqueles que se foram, com pulmões alagados ${ }^{4}$.

Discutindo a democratização do cinema no Brasil, não apenas a partir do tocante ao acesso às salas de cinema e às obras cinematográficas mas, mais que isso, elegendo como via paralela e talvez principal a necessidade da existência de um universo mais plural de produtores fílmicos e incluindo entre eles os próprios professores, os textos agrupados por este dossiê promovem o que Rancière definiu como "o embaralhamento da fronteira entre

\footnotetext{
1 Editora de Seção. Doutora em Educação, Conhecimento, Linguagem e Arte - Faculdade de Educação (UNICAMP). Coordenadora de Pós-Graduação - Faculdades Maria Imaculada. Docente pelo Centro Universitário Padre Anchieta. E-mail: gabi.frigotti@gmail.com.

2 Editora de Seção. Doutora em Educação - PPGE da Universidade Federal de São Carlos (UFSCar). Docente e chefe do Departamento de Ciências Sociais na Educação (DECISE) - Faculdade de Educação (UNICAMP). E-mail: gabigt@unicamp.br.

${ }^{3}$ Em referência à definição de rizoma na teoria filosófica de Gilles Deleuze e Félix Guattari.

${ }^{4}$ Ao Prof. Fernando Henao Granda, um dos autores presentes neste dossiê falecido devido à pandemia antes de seu texto ser publicado, e a todos que hoje choram as dores de afetos perdidos, nosso profundo respeito!
}

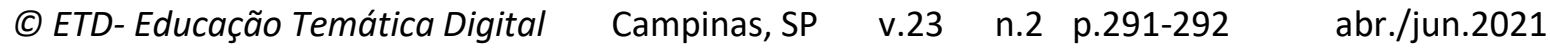


os que agem e os que olham" ${ }^{5}$.

Este é um dossiê que traz textos de autores brasileiros e também argentinos e colombianos, os quais integram uma rede internacional de pesquisa e que exploram aspectos e temas distintos de um projeto comum, se ocupando, dentre outras problemáticas, em pensar acerca da predileção pessoal docente por determinados filmes e das relações entre estas preferências e as escolhas educativas dos docentes. Apresenta, ainda, uma proposta renovadora e esperançosa de tomar como material de cinema as filmagens que fazem parte do cotidiano da própria escola, mas que, por tradição, serviriam como simples registro.

Cabe apontar que as práticas pedagógicas relatadas nos artigos reunidos neste dossiê são oriundas de escolas onde as aulas aconteciam presencialmente, por onde circulavam pessoas e afetos e cuja organização ainda não era atravessada por esse vírus que hoje nos assola e nos impõe novas fronteiras e organizações espaciais. Nesse novo contexto vivido hoje pelas escolas, o debate sobre a presença do cinema e do audio-visual de maneira mais ampla ganha novos contornos e nos requer novas reflexões e perspectivas, para as quais os artigos aqui reunidos tem muito a contribuir.

Nesse sentido, com a publicação deste dossiê, a Revista ETD se presta a revelar agenciamentos produzidos por uma rede que faz borrar as fronteiras entre o antes e o agora, os produtores e apreciadores, e a propor o cinema como forma de expressão, e não apenas de apreciação, traduzindo e poetizando ${ }^{6}$ novas formas de ser e de estar no mundo e na educação e convidando os leitores do referido dossiê e dos demais textos constantes nesta edição a fazer o mesmo. Transigência bastante acertada, sobretudo nestes tempos carentes, porque, cremos, mesmo que silenciosa e suave, sorrateira e vagarosamente, a floresta ainda anda, e sempre andará. ${ }^{7}$

Agradecemos a todos os autores e autoras pela participação nesta edição e desejamos a todes uma boa leitura!

Revisão gramatical realizada por: Fabiano Corrêa da Silva.

E-mail: fabianocosilva@gmail.com.

\footnotetext{
${ }^{5}$ RANCIÈRE, J. O espectador emancipado. Lisboa: Orfeu Negro, 2010, p. 23.

${ }^{6}$ Em referência ao descrito em RANCIÈRE, J. O mestre ignorante - cinco lições sobre a emancipação intelectual. Belo Horizonte: Autêntica, 2015, p. 96.

${ }^{7}$ Em alusão ao documentário Intelligent Trees. (DIR: Julia Dordel e Guido Tölke. ALE, 2016).
}

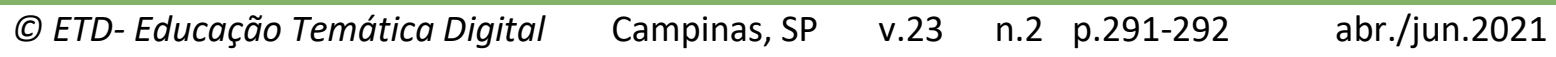

